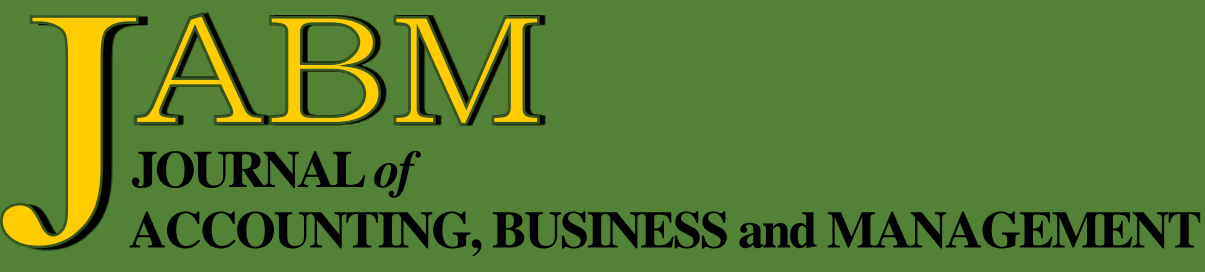

Towards Understanding the Effects of Web 2.0 at the Project Level Knowledge Management on Projects' Success

Anupam Kumar Nath

Sticky Costs and Expenses are not Alike: Mexican Reality

Luis Felipe Llanos Reynoso, César Vela-Beltrán-del-Río, and

José Luis Martínez-Berrones

Business Sustainability Through Environmental and Operational Management in Five Star Hotels in Amman, Jordan

Haitham Abdelrazaq, Taghreed Aljaffal, Pheroza Daruwalla, and

Karina Wardle

Impacts of Asset Utilization, Market Competition and Market

Distance on Stock Returns

Jeanne-Claire Patin, Matiur Rahman, and Muhammad Mustafa

Accounting Conservatism, Information Asymmetry and

Cash Holdings

Walid Shehata and Ahmed Rashed

An Investigation of the Relationship between Corporate Social Responsibility and Corporate Financial Performance in Egypt: The Mediating Role of Information Asymmetry

Nancy Mohamed and Ahmed Rashed

The Impact of Regulatory Capital and Bank Characteristics on the Relationship between Bank Competition and Risk Taking in the Banking System

Eman Abdel-Wanis

Firm Size, Firm Age, and Firm Profitability: Evidence from China Md. Jahidur Rahman and Liu Yilun 
Journal of Accounting, Business and Management vol. 28 no. 1 (2021) 101-115

\title{
Firm Size, Firm Age, and Firm Profitability: Evidence from China
}

\author{
Md. Jahidur Rahman* \\ Liu Yilun ${ }^{\dagger}$
}

\begin{abstract}
This study aims to investigate the relationship among firm size, firm age, and firm profitability in China's stock market. We use data from all the public firms in China's stock market from 2008 to 2018 and adopt a fixed effects model to examine these relationships. We find a positive relationship between firm size and profitability and a negative relationship between firm age and profitability, which is consistent with existing studies conducted in other countries. The findings of our study can contribute to future research in China by offering a sound basis and appropriate reference point, given that no previous research has been conducted in China on this exact topic. This study also offers a comprehensive model for use in future studies.
\end{abstract}

Keywords: firm size, firm age, and firm profitability.

\section{INTRODUCTION}

Firm size has always been an important factor for determining a firm's profitability, which improves performance (Oyelade, 2019); therefore, a firm will always try to increase its size (Oyelade, 2019). Big firms enjoy a larger market share and have more opportunities to make profit; thus, where there is competition, big firms always outcompete small firms (Doğan, 2013). Given their abundant resources, big firms are more likely to break into markets that require high capital rates. Accordingly, the chances for big firms to work in more profitable fields are higher (Doğan, 2013). Although their larger size may bring more profit, some companies are experiencing an annual decline in profitability, even though they are growing in size (Oyelade, 2019). In view of whether the size of the firm has a positive effect on firm profitability, mixed results have been found in studies that have been reviewed (Doğan, 2013). Given these contradictory results, Majumdar (1997) argued that the relationship between firm size and performance is extremely environment-specific and that institutional factors affecting firm profitability can also influence the relationship between firm size and profitability.

Numerous studies have examined the relationship between firm size and profitability. According to Lee (2009) and Doğan (2013), a positive correlation exists between firm size and profitability rate, mainly because of large firms' efficiency gains and high market power. Majumdar (1997) studied the effects of firm age and firm size on performance and found that larger firms tend to have higher profitability but lower productivity, whereas the opposite is true for older firms. Conversely, Banchuenvijit and Phuong (2012) found that firm size is negatively correlated with firm performance, whereas Whittington (1980) found that no significant relationship exists between firm size and firm performance.

\footnotetext{
${ }^{*}$ Corresponding author. Assistant Professor, Department of Accounting, Wenzhou-Kean University, Wenzhou, Zhejiang Province, China. E-mail: mdjahidr@kean.edu.

† Wenzhou-Kean University, Wenzhou, Zhejiang Province, China. E-mail: liuyil@kean.edu.
} 
The relationship between firm age and profitability has also been discussed in abounding studies, although mixed results have been found. Coad et al. (2013) found that a firm's profitability deteriorates with age, given that older firms have difficulties in converting employment growth to profit growth, whereas young firms' expected growth rate is higher. Conversely, Samosir (2018) argued that a company will have more opportunities to attract new investors to improve profitability when it becomes older; thus, firm age positively affects firm profitability. Furthermore, a study suggested a convex relationship between firm age and profitability; that is, a younger firm will realize a profitability decrease, whereas it will be more profitable when it grows older (Akben-Selcuk, 2016).

Existing studies have investigated the relationship among firm size, firm age, and profitability in different countries, including Turkey (Doğan, 2013), the United States (Lee, 2009), India (Majumdar, 1997), Vietnam (Banchuenvijit \& Phuong, 2012), the United Kingdom (Whittington, 1980), and Nigeria (Ilaboya \& Ohiokha, 2016). To date, no research has been conducted in China to investigate the correlation among firm size, firm age, and profitability among Chinese firms. Therefore, the relationship among firm size, firm age, and profitability in China is still unknown. Knowing such relationship will be extremely helpful to Chinese firms that are either in the early stage of development or in the mature stage and have already realized a relatively large economic scale. When a company is analyzing its earnings each year, instead of factors, such as major industrial events and the changing of government policy, the accuracy of the analysis might be affected by the company's age and size. If the effects of firm age and size on earning can be excluded in the company's analysis each year, then the company will be able to obtain a more accurate, comprehensive analysis. Moreover, given that firms will know better about the effects of age and size on their performance, they will be able to make more improved adjustments to their strategies while the firms are expanding and developing into a more mature identity to minimize the side effects on firms' profitability. To fill this gap, this study uses a data sample from China stock market accounting research (CSMAR) to investigate the relationship among firm size, age, and profitability in Chinese companies.

This study uses data of all public firms (excluding financial institutions) from CSMAR for 2008 to 2018 to explore the relationship among firm size, firm age, and profitability in China. In view of the measurement of the variables, we follow the model developed by Ilaboya and Ohiokha (2016) and use profit before interest and tax to measure profitability, total assets to measure firm size, and firm age since incorporation to measure firm age.

The selected data period covers the 2008-2009 financial crisis. Most of the countries had been seriously affected by this crisis, including China, although China recovered quickly and achieved good economic growth (Overholt, 2010). According to Overholt (2010), China's growth mostly comes from domestic sources, instead of export, for two main reasons. First, Beijing reacted decisively to the crisis and announced 4 trillion RMB fiscal stimulus. Moreover, China successfully stimulated a short-term economy by implementing bold monetary stimuli. Although the coverage of financial crisis in our data selection period might affect the accuracy of our results because this time period is at the beginning of our selected data period, not to mention China's quick recovery in the crisis, the effect could be trivial.

This study and its findings can prove to be extremely significant, as it may be a valuable reference for future studies in China on this topic. The data used are a large sample size and include a longer time period, compared with other studies on the same 
topic. This extensive dataset can contribute to more comprehensive results for this research. Moreover, our results may reveal the true relationship among firm size, firm age, and firm profitability, given that mixed results have been found in previous studies. The novelty of this study lies in its wide range of data selection and the country it studies. Different countries have different industrial structures; for example, a larger percentage of the United States and Japan's industrial structures is the service industry, whereas China is still in the process of transforming its economy focus from a secondary sector to a tertiary sector. The study is also unique because China, as the subject of the research, has been experiencing an economic transformation during the past 10 years.

Our study proposes two hypotheses: that positive relationships exist between firm size and profitability and between firm age and profitability. A fixed effects model is adopted, and the findings reveal a positive correlation between firm size and profitability and a negative correlation between firm age and profitability.

This study contributes to the existing literature in several ways. First, this study is the first of its kind that investigates the relationship among firm size, firm age, and firm profitability in China. Second, as we use data from all public firms in China from 2008 to 2018 , this study will provide comprehensive results compared with other studies in different countries, thereby becoming a good reference for future studies. Third, this study contributes to the current literature on the relationships among firm size, age, and profitability by investigating these relationships in the Chinese economic framework. Our results suggest that a positive relationship exists between firm size and profitability and a negative relationship between firm age and profitability.

The remainder of this paper is organized as follows. In section 2, the relevant literature is discussed and summarized, and the hypotheses are developed. Section 3 presents the sample data and explains the empirical models. The results of the study are reported in section 4. Finally, in sections 5 and 6 , the results are interpreted and a conclusion is provided, respectively.

\section{LITERATURE REVIEW AND HYPOTHESIS DEVELOPMENT}

\subsection{Firm Profitability}

According to Ilaboya and Ohiokha (2016), "profitability is the level of profit in relation to the volume of activities of the organization." Although profitability can be used to measure firm performance and efficiency, profitability does not always equal the efficiency of management. Furthermore, profitability and profit are different concepts. According to Horton (2019), profit is the value of the difference between a firm's total revenue and its expense; therefore, it will always be a firm's objective to increase its profit. Profitability, although closely related to profit, is defined as the relationship between a firm's level of profit and its relevant business scale (Horton, 2019). Following the model proposed by Ilaboya and Ohiokha (2016), this study uses profit before interest and tax to measure profitability.

\subsection{Firm Size}

Firm size is one of the core problems in modern enterprise theory, and enterprise (or firm) size still plays an important role in the study of enterprise growth (Wang, 2011). Jiang (2003) defines firm size as "employees per establishment, employees per firm, sales per firm, and value added per firm." Shi (2014) indicated that firm size is the carrier of firm production and business activities. Presently, two criteria exist for enterprise scale classification in the theoretical field: qualitative and 
quantitative indexes. Qualitative division is defined by four main aspects: the degree of enterprise autonomy, the degree of ownership concentration, the management mode, and the status of the industry; quantitative division is defined mainly by the number of employees, the firm's assets, and its sales income (Shi, 2014). In previous related studies, firm size is measured by a firm's total assets, its net sales, and the number of employees. Following Ilaboya and Ohiokha (2016), this study uses the total assets as the measurement of firm size.

\subsection{Firm Age}

Age is defined as "the time of life at which some particular qualification, power, or capacity arises or rests" (Merriam-Webster, 2019). According to Ilaboya and Ohiokha (2016), a firm's age is "the number of years of incorporation of the firm." However, some argued that listing should be used to define firm age, as listing is more economical and because a firm's life starts from the moment of listing (Shumway, 2001). Others refuted this argument by stating that a firm is born though incorporation as a legal entity (Götzmann, 2008). Wang (2011) defined firm age as the number of years that the enterprise has experienced from its establishment to the point of investigation; however, if the enterprise terminates at the point of investigation, it can also be called the life of the enterprise. Similar to Ilaboya and Ohiokha (2016), we use the age of the firm since incorporation to measure firm age.

\subsection{Relationship between Firm Size and Profitability}

Since the last century, various studies have investigated the relationship between firm size and profitability. Results were mixed, with some research finding a positive relationship (Hall \& Weiss, 1967; Majumdar, 1997; and Doğan, 2013), some finding a negative correlation (Banchuenvijit \& Phuong, 2012), and some not finding a significant correlation at all (Whittington, 1980). Porter (1985) proposed the "stuck in the middle theory," in which he suggested that small- and large-sized firms have better performance because they can capture niche market more efficiently, whereas mediumsized firms are less competitive and are "stuck in the middle." Amato and Amato (2004) confirmed this point, and they discovered a nonlinear relationship between firm size and profitability and suggested that the nature of economies of scale between firms should be further studied. Moreover, Lee's research used data from over 7,000 US public firms and reached the conclusion that a nonlinear positive size-profitability relationship exists. In addition, studies have found that the relationship between firm size and profitability varies by industries. According to Becker-Blease et al. (2010), this relationship is industry-specific, whereas in most of the industry, firm's ability to make profit is still increasing at a decreasing rate. Wang (2011) addressed the different opinions from these studies that have opposite results. On the one hand, just as Shepherd (1972) mentioned in his early research, relatively larger economies of scale brings large firm more benefits and efficiencies. For instance, large enterprises can generate economic efficiency through mass production; moreover, large enterprises reduce production costs by adopting larger and more efficient production equipment for mass production. These large enterprises also find it easier to hire high-level talents with a high level of management and technological innovation. Conversely, large enterprises have many levels of management, which can lead to distortion in decision making and the control of information, as well as tendencies toward the bureaucratization of management levels (Wang, 2011). The differences in the results of previous studies indicate that future studies are needed to examine this relationship. To further investigate this topic, this study proposes the following hypothesis: 
$\mathbf{H}_{1}$ : a positive relationship exists between firm size and firm profitability.

\subsection{Relationship between Firm Age and Profitability}

Many studies have been conducted to investigate the relationship between firm age and profitability; however, these studies showed mixed results. Guo and Zhang's (2007) research suggested that older firms have a more stable capital structure, as well as more social resources and experiences; therefore, they can spend more time and resources on $\mathrm{R} \& \mathrm{D}$ activities, thereby improving their competitiveness and value. Moreover, younger firms have limited R\&D specialists, budget, or even market information, and blindly investing large amounts of money would not improve their core competitiveness but would rather cause their firm performance to decrease (Guo \& Zhang, 2007). This notion confirms the points raised by Coad et al. (2016) that the innovation activities conducted by younger firms are risker and more unevenly distributed, whereas older firms have more stable innovation. Majumdar (1997) and Doğan (2013) discovered a negative relationship between firm age and profitability; the older a firm is, the more productive but less profitable it will be. Loderer and Waelchli (2010) also found a significant negative relationship between the two variables, and they provided two major reasons to explain this relationship. First, a firm becomes more rigid when it becomes older, which creates corporate inertia, making learning new concepts, accepting changes, and keeping up with the competition difficult for the firm; second, they argued that older firms have poorer corporate governance, rent-seeking behavior is prevalent within the firm, managers slow the labor force growth to secure the existing jobs (Loderer \& Waelchli, 2010). Conversely, the study conducted by Ilaboya and Ohiokha (2016) showed a significant positive relationship between firm age and profitability. The mixed results in the previous research indicate that this relationship should be further examined. To further investigate this topic, this study proposes the next hypothesis:

$\mathbf{H}_{2}$ : a positive relationship exists between firm age and profitability.

\section{RESEARCH SAMPLE AND METHODOLOGY}

\subsection{Data and Source}

We used data from all public firms included in the CSMAR from 2008 to 2018. We randomly selected 50 firms from all the public firms in China. Stock code, company name, and date of establishment were derived from the company profile section. Firm age was calculated using the current year minus the date of establishment. Firms' net profit, interest expense, and income tax expense were derived from the Income Statement section to calculate the EBIT. The total assets is derived from the Balance Sheet section. All the data were sorted in Excel by stock code first and were then imported to Stata15 for further analysis. The sample data were determined following Ilaboya's study. According to Ilaboya and Ohiokha (2016), this data sample choice can provide a larger dataset, which will increase the degree of freedom and minimize the explanatory variables' collinearity problem.

\subsection{Framework and Model Specification}

The framework of this study investigates the relationship among firm size, age, and performance. According to Hannan and Freeman's (1984) theory of structural inertia, the larger an organization is, the more bureaucracy will exist within the organization. This condition can lead to the organization becoming inflexible and unwilling to change, possibly leading to a decrease in the organization's profitability. 
Therefore, a functional relationship exists between firm size and profitability. According to Ilaboya and Ohiokha (2016), this relationship can be expressed as follows:

Profitability $=f($ FSIZE $)$

According to the theory of learning by doing, proposed by Garnsey (1998), a firm's productivity can be enhanced by increasing knowledge of productive production techniques. The longer a firm has been operating, the more resources, more allies in the industry, and the more management experience it will possess. Hence, a functional relationship exists between firm age and profitability. According to Ilaboya and Ohiokha (2016), this relationship is expressed by the following equation:

Profitability $=f(\mathrm{FAGE})$ as follows:

Next, a new equation is formed by combining equations (1) and (2), as shown

\section{Profitability $=f($ FSIZE, FAGE $)$}

Following Ilaboya's model, this study introduces the control variable board size, which will transform equation (3) into

Profitability $=f($ FSIZE, FAGE, BSIZE $)$ as follows:

Equation (4) can similarly be expressed in econometric form, as shown

$$
\begin{aligned}
& \text { LPBIT }=\beta_{0}+\beta_{1} \text { FSIZE }+\beta_{2} \text { FAGE }+\beta_{3} \text { BSIZE }+\varepsilon \ldots \ldots \\
& \text { LPBIT }_{i t}=\beta_{0}+\beta_{1} \text { FSIZE }_{i t}+\beta_{2} \text { FAGE }_{i t}+\beta_{3} \text { BSIZE }_{i t}+\varepsilon_{i t}
\end{aligned}
$$

Where:

1). LPBIT is the log of profit before interest and tax,

2). LFSIZE is the log of total assets that measures FSIZE,

3). FAGE is the firm age of incorporation,

4). BSIZE is the board size,

5). $\varepsilon$ is the error term, i represents the firm, and tenotes the time covered.

This study adopts Stata15 as a statistical tool to test the hypotheses. Table 1 shows the definitions of all the variables-profitability, firm size, firm age, and board size.

Table1

Variable Definitions

\begin{tabular}{cclc}
\hline \multicolumn{1}{c}{ Variable } & Code & \multicolumn{1}{c}{ Definition } & Source \\
\hline Profitability & PBIT & $\begin{array}{l}\text { Log of profit before interest and tax (llaboya \& } \\
\text { Ohiokha, 2016) }\end{array}$ & CSMAR \\
Firm Size & FSIZE & $\begin{array}{l}\text { Log of total assets (Ilaboya \& Ohiokha, 2016) } \\
\text { Firm Age }\end{array}$ FAGE & $\begin{array}{l}\text { Age of the company since incorporation (Ilaboya } \\
\text { \& Ohiokha, 2016) } \\
\text { Total number of board (Ilaboya \& Ohiokha, CSMAR } \\
\text { 2016) }\end{array}$ \\
\hline
\end{tabular}

\section{EMPIRICAL RESULTS}

\subsection{Descriptive Statistics}

The CSMAR data from 2008 to 2018 yielded 20,515 observations; however, some of the firms chose not to reveal their financial data in certain years. We excluded observations with missing data, which decreased the total number of observations for BSIZE, FAGE, FSIZE, and LPBT to 16,935. Furthermore, there existed few years when some firms showed a negative profit before interest and tax. When calculating the $\log$ of the profit before interest and tax, these observations would not have a valid result. Hence, we excluded these observations, and the number of observations for 
LPBT thus decreased from 16,935 to 13,918. Table 2 shows a detailed summary of the descriptive statistics.

In view of board size, among all the firms we selected, the maximum number of board members were 18 people, and the minimum was 1 person. The mean for the board size is therefore nine members; thus, the selected firms have an average board size of nine members. The selected firms have a maximum firm age of 61 years, a minimum age of 1 year, and a mean of 18 years. The firm size was calculated by the log of the firm's total assets. Among the selected firms, the largest firm had a firm size of 12.38606, equal to 2,432 billion RMB in total assets, whereas the minimum firm size was 4.708707 (51,133.68 RMB in total assets), and the average firm size was 9.645708 (4.423 million RMB). The maximum profit before interest and tax of all the firms was 11.27364 (187.777 billion RMB), and the minimum was 4.321476 (20,000.964 RMB), with an average of 8.356638 (227.32 million RMB).

The standard deviations for BSIZE, FAGE, LFSIZE, and LPBT were 1.947865, $5.808731,0.662388$, and 0.7303054 , respectively. Thus, the data in all the four datasets were highly concentrated to their means and had a low level of dispersion. The values of skewness for BSIZE, FAGE, LFSIZE, and LPBT were 0.5971423, 0.5403579, 0.2207923 , and -0.0939148 , respectively. Thus, among the four variables, BSIZE, FAGE, and LFSIZE were positively skewed, which indicates that the right tails of their distribution were longer than their right tails. However, LPBT was negatively skewed, which suggests that the left tail of its distribution was longer than its right tails. The values of kurtosis for BSIZE, FAGE, LFSIZE, and LPBT were 5.912886, 4.87125, 4.341174 , and 4.227778 respectively. These values were all larger than 3 , which suggests that the four variables had high peaks near the center of their distribution.

Table 2

Summary of the Descriptive Statistics

\begin{tabular}{lcccc}
\hline & BSIZE & FAGE & FSIZE & LPBT \\
\hline Mean & 8.916 & 18.386 & 9.646 & 8.357 \\
Median & 9.000 & 18.000 & 9.597 & 8.344 \\
Maximum & 18.000 & 61.000 & 12.386 & 11.274 \\
Minimum & 1.000 & 1.000 & 4.709 & 4.321 \\
Std. Deviation & 1.948 & 5.808 & 0.662 & 0.730 \\
Skewness & 0.597 & 0.540 & 0.221 & -0.0939 \\
Kurtosis & 5.913 & 4.871 & 4.341 & 4.228 \\
Sum & 150,993 & 311,369 & $163,350.1$ & $116,307.7$ \\
Observations & 16,935 & 16,935 & 16,935 & 13,918 \\
\hline
\end{tabular}

Note: this study uses all public firms, except for financial institution data, from CSMAR from 2008 to 2018. We remove (1) 3,580 observations that do not reveal their financial data and (2) 3,017 observations that have a negative profit before interest and tax.

\subsection{Spearman's Rank Order Correlation Test}

Following Ilaboya's model, this study adopts a Spearman's rank order correlation. Table 3 shows the results of this test. As shown in Table 3, a correlation of 1.00 existed among the variables. The rest of the correlations all showed high significant levels (0.000), which suggests that the variables were all independent of one another without multicollinearity problems. All of the variables showed a positive correlation, except for FAGE and BSIZE, which showed a negative correlation. Next, we conducted a variance inflation factor test to further address multicollinearity. 
Table 3

Result of the Spearman Rank-Order Correlation Test

\begin{tabular}{ccccc}
\hline $\begin{array}{l}\text { Correlation } \\
\text { Number of Observation } \\
\text { Significant Level }\end{array}$ & & & & \\
\cline { 2 - 5 } BSIZE & BSIZE & FAGE & FSIZE & LPBIT \\
\hline & 1.000 & & & \\
FAGE & 13918 & & & \\
& -0.0361 & 1.000 & & \\
FSIZE & 13918 & 13918 & & \\
& 0.000 & & & \\
& 0.250 & 0.143 & 1.000 & \\
LPBIT & 13918 & 13918 & 13918 & \\
& 0.000 & 0.000 & & 1.000 \\
& 0.202 & 0.0442 & 0.811 & 13918 \\
& 13918 & 13918 & 13918 & \\
& 0.000 & 0.000 & 0.000 & \\
\hline
\end{tabular}

Note: three attributes exist in each interaction between two variables; these attributes are correlation, number of observations, and significant level.

\subsection{Variance Inflation Factor Test}

As shown in Table 4, the variance inflation factors for BSIZE, FAGE, and FSIZE were 1.08, 1.01, and 1.09, respectively, which were considerably lower than the benchmark of 10.00. This result further confirmed that the variables were all independent of one another and that no multicollinearity existed among them. With this confirmed, we moved on to the panel least squares regression.

Table 4

Result of Variance Inflation Factor Test

\begin{tabular}{llc}
\hline \multicolumn{1}{c}{ Variable } & VIF & 1/VIF \\
\hline BSIZE & 1.08 & 0.924 \\
FAGE & 1.01 & 0.990 \\
FSIZE & 1.09 & 0.917 \\
\hline Mean VIF & 1.06 & \\
\hline
\end{tabular}

\subsection{Panel Least Squares Regression}

In Table 5, the panel least squares regression showed an F-statistic of 7,754.13 and a related probability of 0.000 , which suggests that the null hypothesis of the F-test was rejected, that the regression model had an explanatory power, and that significant relationships existed between the firms' profitability and board size, firm age, and firm size. The panel least squares regression also showed an R-squared value of 0.626 and an adjusted R-squared value of 0.626 , suggesting that $62.6 \%$ of the variation in firms' profitability could be explained by the independent variables BSIZE, FAGE, and FSIZE. Moreover, the regression model fitted the data well. The coefficient of correlations showed negative relationships among board size, firm age, and firm profitability and a positive correlation between firm size and firm profitability. 
Table 5

Result of Panel Least Squares Regression

\begin{tabular}{ccccc}
\hline Variable & Coefficient & Std. Error & t-Statistic & Prob. \\
\hline C & 0.818 & 0.00312 & 262.45 & 0.000 \\
BSIZE & -0.000161 & 0.000106 & -1.52 & 0.129 \\
FAGE & -0.000454 & 0.0000342 & -13.28 & $0.000^{* * *}$ \\
FSIZE & 0.0488 & 0.000332 & 147.05 & $0.000^{* * *}$ \\
\hline R-Squared $=0.626$ & & & \\
Adj R-Squared $=0.626$ & & \\
F-Statistic $=7754.13$ & & \\
Prob. (F-Statistic) $=0.000$ & & \\
Note: $* * * \mathrm{p}<0.01, * * \mathrm{p}<0.05$, and ${ }^{*} \mathrm{p}<0.1$. &
\end{tabular}

\subsection{Chow Test}

The result of the Chow test is shown in Table 6. The result of the Chow test indicated an F calculated value of 6.32 , whereas the F critical value calculated by using "at invFtail (1,847, 1,2067, .05)" in Stata15 was considerably smaller than the F calculated value. Thus, the null hypothesis of Chow test was rejected.

Table 6

Chow Test

\begin{tabular}{|c|c|c|c|c|}
\hline Variable & Coefficient & Robust Std. Error & t-Statistic & Prob. \\
\hline $\mathrm{C}$ & 0.7793194 & 0.0075932 & 102.63 & 0.000 \\
\hline BSIZE & 0.000161 & 0.0001682 & 0.96 & 0.338 \\
\hline FAGE & -0.0007446 & 0.0000764 & -9.75 & $0.000^{* * *}$ \\
\hline LFIZE & 0.0530213 & 0.0008701 & 60.94 & $0.000 * * *$ \\
\hline $\begin{array}{l}\text { F test that } \\
F(1,847,1, \\
\text { F calculatec } \\
\text { Prob. }>\text { F }\end{array}$ & $\begin{array}{l}\mathrm{i}=0 \\
7)=6.32 \\
\text { lue }=1.5059 \\
0000\end{array}$ & & & \\
\hline
\end{tabular}

\subsection{Hausman Test}

We used Hausman test to determine whether to adopt a fixed effects or a random effect model. Table 7 shows the results. The result of the Hausman Test indicated a probability value of 0.000 . Thus, the null hypothesis of a random effect model being the preferred model was rejected. This study therefore adopted a fixed effects model.

\section{Table 7}

Result of Hausman Fixed/Random Effects

\begin{tabular}{|c|c|c|c|c|}
\hline & \multicolumn{2}{|c|}{ Coefficients } & \multirow[b]{2}{*}{ (b-B) } & \multirow{3}{*}{$\begin{array}{c}\operatorname{Sqrt}\left(\operatorname{diag}\left(V_{-} b-V_{-} B\right)\right. \\
\text { S.E. }\end{array}$} \\
\hline & (b) & (B) & & \\
\hline & fe & re & Difference & \\
\hline$\overline{B S I Z E}$ & 0.000161 & -0.000137 & 0.000298 & 0.0000912 \\
\hline FAGE & -0.000745 & -0.000560 & -0.000185 & 0.0000573 \\
\hline FSIZE & -0.0530 & 0.0500 & 0.00306 & 0.000683 \\
\hline Test: & \multicolumn{4}{|c|}{$\begin{array}{l}\mathrm{H}_{0}: \text { difference in coefficients not systematic } \\
\text { Chi2 }(3)=(\mathrm{b}-\mathrm{B})^{\prime}\left[\left(\mathrm{V}_{-} \mathrm{b}-\mathrm{V}_{-} \mathrm{B}\right)^{\wedge}(-1)\right](\mathrm{b}-\mathrm{B})=30.81 \\
\text { Prob. }>\text { Chi2 }=0.000\end{array}$} \\
\hline
\end{tabular}




\subsection{Lagrange Multiplier (LM) Test}

We used the LM test to determine if a significant difference exists across the units. Table 8 shows the results. The result of the LM test showed a probability value of 0.000 , which indicated no variances in the panel data. Thus, the null hypothesis of "That is, no significant difference across units (i.e., no panel effect)" was rejected. Panel effect existed in the dataset, and this study should proceed the panel data analysis.

Table 8

Result of LM Test

\begin{tabular}{ccc}
\hline \multicolumn{3}{l}{ Estimated Results: } \\
\hline LPBIT & Var & Sd= Sqrt (Var) \\
\hline e & 0.710544 & 2.170379 \\
$\mathbf{u}$ & 0.62906951 & 0.8089558 \\
Test: & Var $(\mathrm{u})=0$ \\
& Chibar2 $(01)=262.56$ \\
& Prob. > Chibar2=0.000 \\
\hline
\end{tabular}

\subsection{Fisher-type Unit Root Test for Data Stationary}

We used the Fisher-type unit root test to determine if the data were stationary in this model. Table 9 shows the result of the test. All of the results of the Fisher-type test indicated probability values of 0.000 . Thus, the null hypothesis of "all panels contain unit roots" was rejected. The data in all the panels were stationary.

Table 9

Result of Fisher-type Unit Root Test

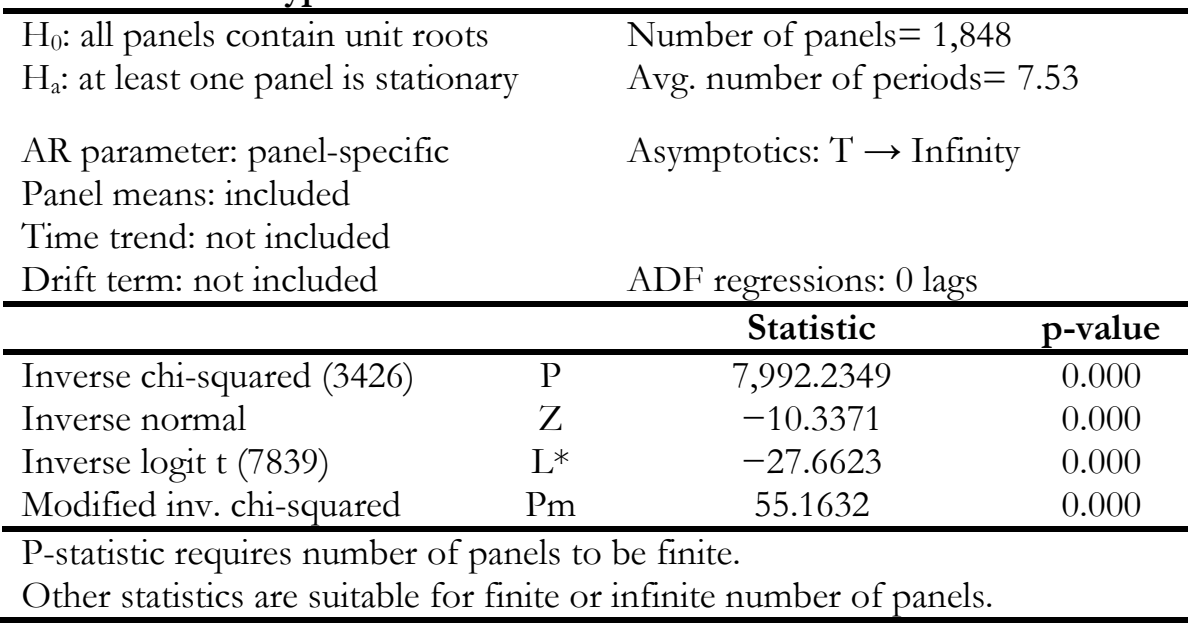

\subsection{Fixed Effects Model}

The results of the fixed effects model showed an F-statistic of 1,976.29 and a probability value of 0.000 , which suggests that the regression model was highly significant. The R-squared value for the fixed effects model was 0.682 , indicating that $68.2 \%$ of the variance in the firms' profitability could be explained by the independent variables BSIZE, FAGE, and FSIZE.

These results indicated that firm size was found to have a highly significant relationship with firm profitability. Table 7 shows a t-statistic of 60.94 and a probability of 0.000 . The positive correlation of 0.0530 suggests that the firm's profitability would experience an increase of $5.30 \%$ if the firm size increased, thereby confirming our 
hypothesis of a positive relationship between firm size and profitability. This result also confirms the findings of previous studies (Majumdar, 1997; Ilaboya \& Ohiokha, 2016; and Oyelade, 2019). However, the result contradicts the results of some early studies on this topic, which states that no significant relationship exists between firm size and profitability (Hall \& Weiss, 1967; Whittington, 1980).

The results of the fixed effects model also indicated a highly significant relationship between firm size and firm profitability. Table 7 shows a t-statistic of -9.75 and an associated probability of 0.000 . The coefficient of -0.000745 suggests that a negative correlation existed between firm age and firm profitability; thus, a firm's profitability would decrease slightly if the firm age increased. This result contradicts our second hypothesis of a positive relationship between firm age and profitability; thus, the second hypothesis was rejected. This negative correlation confirms some previous studies (Majumdar, 1997; Doğan, 2013), whereas it contradicts some other findings that observed a positive relationship between these variables (Banchuenvijit \& Phuong, 2012; Ilaboya \& Ohiokha, 2016).

As shown in Table 7, an insignificant but positive relationship existed between board size and firm profitability. The result showed a coefficient of 0.000161 , a t-statistic of 0.96 , and a profitability value of 0.338 . Although the result was insignificant, the positive correlation confirmed our expectations that there a positive relationship existed between board size and firm profitability.

Table 10

Result of Fixed Effects Model

\begin{tabular}{ccccc}
\hline Variable & Coefficient & Std. Error & t-Statistic & Prob. \\
\hline C & 0.779 & 0.00759 & 102.63 & 0.000 \\
BSIZE & 0.000161 & 0.000168 & 0.96 & 0.338 \\
FAGE & -0.000745 & 0.0000764 & -9.75 & $0.000^{* * *}$ \\
FSIZE & 0.0530 & 0.000870 & 60.94 & $0.000^{* * *}$ \\
\hline R-Squared $=0.682$ & & & \\
F-Statistic $=1976.29$ & & \\
Prob. (F-Statistic) $=0.000$ & & & \\
\hline Note: $* * *$ & & & \\
\end{tabular}

\subsection{Robustness Test of Fixed Effects Model}

As shown in Table 8, the coefficient and R-squared values were consistent with the fixed effects model implemented in the analysis. The robustness test had an Fstatistic of 607.61 and a probability of 0.000 , indicating that the model was highly significant. The t-statistics for BSIZE, FAGE, and FSIZE were 0.77, -5.84, and 32.00, and the associated probabilities were 0.442, 0.000, and 0.000, respectively. The t-statistics and probability in this robustness test differed slightly from the fixed effects model conducted previously. However, the overall significant level remained unchanged, which indicates that firm age and firm size were still significantly correlated with firm profitability, whereas the relationship between board size and firm profitability remained insignificant. The robustness test helped eliminate the potential problem of heteroskedasticity and autocorrelation and further confirmed the result of the previous fixed effects model. 
Table 11

Result of the Robustness Test of Fixed Effects Model

\begin{tabular}{ccccc}
\hline Variable & Coefficient & Robust Std. Error & t-Statistic & Prob. \\
\hline C & 0.779 & 0.0144 & 54.25 & 0.000 \\
BSIZE & 0.000161 & 0.000209 & 0.77 & 0.442 \\
FAGE & -0.000745 & 0.000127 & -5.84 & $0.000^{* * *}$ \\
FSIZE & 0.0530 & 0.00166 & 32.00 & $0.000^{* * *}$ \\
\hline R-Squared $=0.682$ & & & \\
F-statistic $=607.61$ & & \\
Prob. (F-statistic) $=0.000$ & & & \\
\hline Note: ${ }^{* * *} \mathrm{p}<0.01,{ }^{* *} \mathrm{p}<0.05$, and ${ }^{*} \mathrm{p}<0.1$. &
\end{tabular}

\subsection{Discussion}

\subsubsection{Main Result}

Our results reveal a highly significant positive relationship between firm size and profitability, a highly significant negative relationship between firm age and profitability, and an insignificant positive relationship between board size and firm profitability. These results show that our proposed first hypothesis- that a positive relationship exists between firm size and profitability-is confirmed, whereas the second hypothesis - that a positive relationship exists between firm age and profitability-is rejected. In summary, this study finds two highly significant relationships between our dependent and independent variables, which fulfills the purpose of the study.

\subsubsection{Unexpected Result and Explanation}

The negative relationship between firm age and firm profitability, rejecting the second hypothesis, is unexpected. Our interpretation of this unexpected result is that the older the firm is, the more rules and regulations will exist within the firm. Moreover, the firm's structure will become more centralized; thus, it takes longer for information to travel from lower to higher levels of management, which in turn makes the decision-making process of the firm to be longer. When the firm is conducting business with other firms in the capital market, employees may be bound by complicated regulations within the firm, thereby decreasing efficiency and leading to a probability for the firm to suffer losses due to this inefficiency. As mentioned in the previous section, this unexpected result confirms the results of some early studies (Majumdar, 1997; Doğan, 2013). However, these studies' interpretations of the results are based on the economic framework in their countries (e.g., India and Turkey). Therefore, their interpretations cannot possibly explain our results. Existing studies in China on a related topic are also available. Lei et al. (2014) found that political resource enterprises with a shorter listing age exceeds political resource enterprises with a longer listing age in terms of capital turnover efficiency-reflected by the turnover ratio of total assets and accounts payable-and the working capital guarantee capabilityreflected by the multiple of surplus cash and the investment ratio of cash satisfaction. They suggested that the gradual expansion of a firm's operation and production scale causes older firms' operating efficiency to decrease, which implies that the firm's performance is affected by "growth inertia" (Lei et al., 2014). Moreover, "indigestion" caused by the oversupply of resources in older firms can also lead to lower operating efficiency (Lei et al., 2014). Their explanation partly conforms to our interpretation on this unexpected result. 


\subsubsection{Reliability and Validity}

The results of our study are wholly consistent with Majumdar's research, which also found that larger firms tend to be more profitable and that older firm are less profitable. His interpretation of the results indicates that larger firms have larger market power because they preempted a large amount of market capacity, which provides more opportunities to earn higher profits (Majumdar, 1997). He also stated that the older firms in India failed to realize that the dominant power in the market had switched from government to customer and that a lack of a competitive culture led to older firms in India being less profitable (Majumdar, 1997). The results of the current study is in line with his first interpretation of larger companies being more profitable; however, they do not agree with the second interpretation on firm age. China has a completely different market than India; therefore, the explanations for why older firms in India are less profitable might not be applicable to Chinese firms. To further investigate this matter, future studies should focus specifically on the relationship between firm age and firm profitability to provide detailed explanations for this result. Although this study has several limitations, the results are accurate and significant. Furthermore, as the data are collected from the CSMAR, no extraneous variables can affect the model, and no validity problem exists in this study.

\subsubsection{Theoretical Contribution}

In this study based on the Chinese stock market, firm age, size, and profitability are the main variables. The data in this study range from 2008 to 2018 and include all the listed companies on the Chinese stock market. The long study period and relatively large data sample provide comprehensive results and can benefit future studies on the same topic. Previous research on this topic had all been conducted in other countries with different market structures; thus, the conclusions based on these other studies' results cannot be applied to the results of the present work. Given that no research in China on this topic exists, the results of this study offer a high reference value for future studies. Lastly, future studies should be conducted to examine the relationships addressed in this work in different industries, and they could also incorporate data on private firms in China.

\section{CONCLUSION}

This study investigated the relationships among firm size, firm age, and firm profitability and found a significant positive relationship between firm size and profitability and a negative relationship between firm age and profitability. This study is highly relevant because it uses a large data sample of all public firms in China, and studies that examine these relationships in the Chinese stock market have been few. The study period-from 2008 to 2018-provides data across a longer time period than other studies on the same topic. The extensive dataset contributes to more comprehensive results, which can become a valuable reference for future studies on this topic.

In view of the limitations, this study only included data of public firms in China and excludes private firms. Therefore, the result might be different if private firms' data are incorporated in this model. The study also failed to consider the effects of firm size and firm age on firm profitability by different industries, and the probability of different industries generating different results should be considered. In addition, firms with negative profit were excluded from the model, which suggests that the results are only applicable to firms with positive earnings. 
Future studies should incorporate private firms in the model to obtain a more comprehensive result. Furthermore, future studies should address the effects of firm age and firm size on profitability by different industries and present their results by each industry. Lastly, future studies should attempt to find a way to study these relationships in companies with a negative profit.

\section{REFERENCES}

Akben-Selcuk, E. (2016). Does firm age affect profitability? Evidence from Turkey. International Journal of Economic Sciences, 5(3), 1-9. Doi: 10.20472/ES.2016.5.3.001.

Amato, L. H., \& Amato, C. H. (2004, May). Firm size, strategic advantage, and profit rates in US retailing. Journal of Retailing \& Consumer Services, 11(3), 181-193.

Banchuenvijit, W., \& Phuong, N. T. H. (2012). Determinants of firm performance of Vietnam listed companies. Academic \& Business Research Institute, 1-7. Retrieved from http:// aabri.com/SA12Manuscripts/SA12078.pdf.

Becker-Blease, J. R., Kaen, F. R., Etebari, A., \& Baumann, H. (2010, April). Employees, firm size and profitability of US manufacturing industries. Investment Management \& Financial Innovations, 7(2), 7-23. Retrieved from https://www.businessperspectives.org/images/pdf/applications/publishing/te mplates/article/assets/3235/imfi_en_2010_02_Becker.pdf.

Coad, A., Segarra, A., \& Teruel, M. (2013, March). Like milk or wine: Does firm performance improve with age? Structural Change \& Economic Dynamics, 24(C), 173-189.

Coad, A., Segarra, A., \& Teruel, M. (2016, March). Innovation and firm growth: Does firm age play a role? Research Policy, 45(2), 387-400.

Doğan, M. (2013, April). Does firm size affect the firm profitability? Evidence from Turkey. Research Journal of Finance \& Accounting, 4(4), 53-59.

Garnsey, E. (1998, September). A theory of the early growth of the firm. Industrial \& Corporate Change, 7(3), 523-556.

Götzmann, N. (2008, January). Legal personality of the corporate and international criminal law: Globalisation, corporate human rights abuses and the Rorne statue. Queensland Law Student Review, 1(1), 38-54.

Guo, M., \& Zhang, P. (2007). Empirical research on enterprise age, R\&D investment and performance - evidence from empirical data of a-share listed companies in Zhejiang province. Communication of Finance \& Accounting, 36.

Hall, M., \& Weiss, L. (1967, August). Firm size and profitability. The Review of Economics \& Statistics, 49(3), 319-331.

Hannan, M. T., \& Freeman, J. (1984, April). Structural inertia and organizational change. American Sociological Review, 49(2), 149-164.

Horton, M. (2019). The difference between profitability and profit. Retrieved from https://www.investopedia.com/ask/answers/012715/what-differencebetweenprofitability-and-profit.asp.

Ilaboya, O. J., \& Ohiokha, I. F. (2016, March). Firm age, size and profitability dynamics: A test of learning by doing and structural inertia hypotheses. Business \& Management Research, 5(1), 29-39.

Jiang, T. (2003, December 15-17). Firm size and IT investment: Beyond simple averages. Publised in $24^{\text {th }}$ International Conference on Information Systems (ICIS), Seattle, Washington.

Lee, J. (2009, July). Does size matter in firm performance? Evidence from US public firms. International Journal of The Economics of Business, 16(2), 189-203. 
Lei, H., Liang, Q., \& Li, J. (2014). Does the ultimate control and age of the company affect the operational efficiency of China's political resource enterprises? -- Nonparametric testing of Chinese listed companies. Economic Management Journal, 7.

Loderer, C. F., \& Waelchli, U. (2010, April). Firm age and performance. Retrieved from https://ssrn.com/abstract=1342248 or http://dx.doi.org/10.2139/ssrn.1342248

Majumdar, S. K. (1997, April). The impact of size and age on firm-level performance: Some evidence from India. Review of Industrial Organization, 12(2), 231-241.

Merriam-Webster.com. (2019). Definition of age (entry 1 of 3). Retrieved August 18, 2019, from https://www.merriam-webster.com/dictionary/age.

Overholt, W. H. (2010, January). China in the global financial crisis: Rising influence, rising challenges. The Washington Quarterly, 33(1), 21-34.

Oyelade, A. O. (2019, January). The impact of firm size on firms performance in Nigeria: A comparative study of selected firms in the building industry in Nigeria. Asian Development Policy Review, 7(1), 1-11.

Porter, M. E. (1985). Competitive advantage: Creating and sustaining superior performance $\left(3^{\mathrm{rd}}\right.$ ed.). New York, NY: The Free Press.

Samosir, F. C. (2018, March). Effect of cash conversion cycle, firm size, and firm age to profitability. Journal of Applied Accounting \& Taxation, 3(1), 50-57.

Shepherd, W. G. (1972, February). The elements of market structure. The Review of Economics \& Statistics, 54(1), 25-37.

Shi, J., (2014). Empirical research on the relationship between firm size and firm performance. Journal of Ocean University of China (Social Sciences), 5.

Shumway, T. (2001). Forecasting bankruptcy more accurately: A simple hazard model. The Journal of Business, 74(1), 101-124.

Wang, F. (2011). Enterprise size, performance, age and enterprise survival: Theory and re-cognition. Future \& Development, 7.

Whittington, G. (1980). The profitability and size of United Kingdom companies, 196074. The Journal of Industrial Economics, 28(4), 335-352. 